\title{
JOURNAL.RU
}

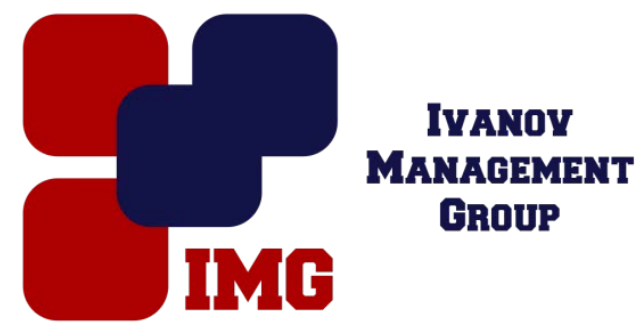

Хряпин Ю.Н. Рязанское высшее воздушно-десантное командное училище имени генерала армии В.Ф.

Маргелова

Рязань, Россия

doi: 10.18411/lj-30-11-2016-2-13

idsp 000001:lj-30-11-2016-2-13

\section{Реализация компетентностного подхода в военном вузе - важнейшее условие подготовки офицера-профессионала}

\section{Аннотация}

В статье раскрываются сущность и структура компетентности, условия эффективного развития военно-профессиональной компетентности будущих офицеров.

Ключевые слова: компетентность, компетенция, профессиональная компетентность, военно-профессиональная компетентность.

Implementation of a competence approach in the military College is the most important condition of training of officer-professional.

\section{Abstract}

The article reveals the essence and structure of competence, conditions for effective development of military-professional competence of future officers.

Key words: competence, competence, professional competence, professional military competence.

Одним из основных противоречий современной подготовки будущих специалистов является несоответствие между требуемым и реальным уровнем готовности выпускников вузов исполнять свои функциональные обязанности. Образовательный процесс часто ориентирован на приобретение знаний, но не достаточно формируется профессиональная компетентность, предполагающая иметь прочные практические навыки. В этой связи в системе непрерывного образования при формировании профессиональной компетентности профессионала компетентностный подход призван сыграть ведущую роль.

Основные положения компетентностного подхода в системе современного российского образования, узловое понятие которого - компетентность, было сформулировано в российском документе "Стратегии модернизации содержания 
общего образования" [1]. Где подчеркнуто, что понятие компетентность шире понятия знания, или умения, или навыка; оно включает их в себя и включает не только когнитивную и операционально-технологическую составляющие, но и мотивационную, этическую, социальную и поведенческую.

В психолого-педагогической литературе понятие «компетентность» связано с определенным видом деятельности. Так, компетентность по Новикову А.М. означает самостоятельно реализуемую способность к практической деятельности, к решению проблем, основанная на приобретенных обучающимися учебном и практическом опыте, умении, его ценностях и склонностях [2].

А.Г. Пашковым профессиональная компетентность определяется как «интегральная характеристика деловых и личностных качеств специалиста, отражающая не только уровень знаний, умений, навыков, опыта, достаточного для достижения целей профессиональной деятельности, но и социальнонравственную позицию личности» [3].

Маркова А.К. при рассмотрении профессиональной компетентности выделяет три ее составляющие [4]:

1. Социальный и профессиональный статус.

2. Практическую готовность (деятельность) и продукты деятельности (теоретическую готовность).

3. Профессионально-значимые личностные особенности, т.е уровень индивидуального адаптированности к профессиональной деятельности.

Следовательно, профессиональная компетентность, является необходимой составляющей профессионализма человека как особое свойство людей систематически, надежно и эффективно исполнять функциональные обязанности с заданными показателями качества, соответствующим принятыми в обществе стандартам и объективным требованиям.

Говоря о профессиональной компетентности подразумевают способность специалиста успешно решать профессиональные задачи, определяемые моделью деятельности специалиста. Н.Ф. Талызина и другие авторы [5] отмечают, что модель деятельности специалиста должна определять систему задач, которые встают перед ним после окончания обучения.

Структурно содержание профессиональной компетентности включает совокупность ключевых, базовых и специальных компетенций [6].

Базовые компетенции должны отражать современное понимание основных задач профессиональной деятельности, а ключевые - охватывать алгоритм их решения. Специальные же компетенции реализуют базовые и ключевые применительно к специфике профессиональной деятельности конкретного специалиста. Ключевые, базовые и специальные компетенции, пронизывая друг друга, проявляются в процессе решения жизненно важных профессиональных задач разного уровня сложности в разных контекстах.

Компетенции, как «наполнение» компетентности формируются в процессе обучения, и не только в школе, но и под воздействием семьи, друзей, работы, 
политики, религии, культуры и пр. Г. Сартан пишет: «Компетенция - это совокупность индивидуальных и профессиональных характеристик работника, определяющих качественное выполнение работы. Компетенции определяют стандарт эффективного выполнения работы» [7].

Переходя к рассмотрению военно-профессиональной компетентности следует отметить, что оно является сложным и многоаспектным, поскольку разносторонней является и сама воинская деятельность. В ней выделяются взаимосвязанные, объединенные социальными целями и задачами стороны: учебно-боевая, профессиональная и служебная деятельность, повседневные отношения, в которых осуществляется развитие конкретного военнослужащего и воинских коллективов и достигаются результаты воинского труда боеготовность, морально-психологическое состояние военнослужащих, дисциплина и др. Военно-профессиональная компетентность выпускника военного вуза определяются сформированностью у офицера комплекса качеств, отвечающих требованиям, целям, задачам и характеру современного воинского труда.

Целеполагание в условиях военного вуза формулируется в виде «социального заказа общества» на основе двух документов: Государственного образовательного стандарта высшего профессионального образования (ГОС ВПО) и квалификационных требований к военно-профессиональной подготовке выпускников, в совокупности определяющих те качества, знания, умения и навыки, которые должны быть сформированы у будущего офицера за период обучения в вузе за счет бюджета времени, выделенного на изучение блока военно-профессиональных дисциплин.

Выпускник военного вуза должен быть компетентным в следующих видах военно-профессиональной деятельности: [8]

- организационно-управленческой (боевой и повседневной);

- обучающей и воспитательной;

- военно-технической;

- научно-исследовательской.

Виды деятельности «наполняются» группами компетенций (OK, ПК, ПКс) и набором вполне конкретных компетенций, на освоение которых направленно содержание образовательного процесса. Каждая компетенция из соответствующей группы компетенций, должна иметь подробное описание содержания процесса еe формирования и зафиксирована в определенном документе.

K структурным элементам военно-профессиональной компетентности относятся [9]:

- военно-профессиональные знания;

- система профессионально важных навыков и умений;

- военно-профессиональные позиции;

- личностные качества (особенности); 
- готовность и способность решать разнообразные задачи, возникающие в воинской деятельности.

В структуре профессиональной компетентности выпускника военного вуза выделяют две основные составляющие: [9].

когнитивно-операциональную, отражающую «стратегию» воинского труда и включающую в себя: военно-профессиональные знания, умения и навыки;

профессионально-личностную, объединяющую интегральные характеристики формирующейся личности и включающую профессиональное самосознание, индивидуальный стиль деятельности и общения, творческий потенциал будущего военного специалиста.

Необходимо отметить, что в структуре профессиональной компетентности выпускника военного вуза обе составляющие находятся в сложных диалектических отношениях, которые проявляются в том, что каждая из них является то предпосылкой, то средством, то результатом развития другой (например, в начале профессионально-личностная составляющая является условием, приспосабливается к требованиям когнитивно-операциональной составляющей, а затем сама строит и развивает ее).

На наш взгляд принципиально важным является сформированность у военного специалиста не только профессиональных, но и личностнопрофессиональных качеств. Важно не только какая профессиональная компетентность сформирована у специалиста, но и как ими личность офицера будет распоряжаться.

Планирование (проектирование) профессиональной подготовки в военном вузе в силу специфики его деятельности осуществляется строго в соответствии с нормативными документами, Уставами и инструкциями и не допускает изменений в содержательной части. Необходимо в блоках изучаемых общепрофессиональных, военно-профессиональных, гуманитарных и социально-экономических дисциплин максимально реализовывать потребности компетентностного подхода.

При формировании и развитии профессиональной компетентности военного специалиста выделяют ряд этапов. Первый ориентирован на развитие ключевых компетентностей в контексте будущей деятельности. На втором этапе происходит «по гружение» обучающегося в профессиональные задачи, при этом он осваивает способы их решения, содействующие становлению базовой компетентности на основе ключевых. Так осуществляется интеграция базовой и ключевой компетентностей. Третий этап характеризуется проекцией (проникновением, интеграцией) базовой компетентности, уже неразрывно связанной с ключевой и специальной. Затем реализуется этап развития специальной компетентности.

Эффективный процесс формирования военно-профессиональной компетентности невозможен без контроля и оценки формирования и развития отдельных компетенций, процесса. Результаты каждого этапа и 
сформированность каждой отдельной компетенции должны быть четко прописаны в соответствующих документах. Важно иметь механизм учета и оценки сформированности компетенций в образовательном процессе, что является далеко не простым делом.

Так по М.А. Лямзину [10] разработчикам содержания процесса формирования компетенций необходимо ответить на многие вопросы, среди которых одним из основных является ответ на вопрос: сколько потребуется времени в зачетных единицах и академических часах для формирования конкретной компетенции?

В вузах часто пытаются решить проблему формирования отдельно взятой компетенции (или группы компетенций) без научного просчета трудозатрат, ориентируясь на пятигодичный срок обучения. На данный момент никто не может ответить на вопрос сколько потребуется времени в зачетных единицах (академических часах) для формирования конкретной компетенции (группы компетенций)? В этой связи на наш взгляд очень интересный подход сдержится в статье, авторами которой являются Е.В. Кравцов, А.В. Нагалин, Г.А. Сенюков, предлагающие вариант расчета трудозатрат формирования компетенций (в т.ч военно-профессиональных), используя математический аппарат [11].

На наш взгляд, профессионально компетентным может считаться выпускник военного вуза, который: предан профессии офицера, мотивирован к осуществлению военной службы и удовлетворен ею; активно осваивает нормы и эталоны профессии, достигает мастерства в ней, стремится к профессиональному и личностному росту; осознанно развивает свою индивидуальность средствами профессии; успешно решает задачи обучения и воспитания подчиненных, обладая необходимыми для этих целей психологопедагогическими и личностными качествами.

Организационно-педагогическими условиями, способствующими успешному формированию профессиональной компетентности у будущих военных специалистов в вузе являются:

- $\quad$ профессиональный отбор кандидатов для поступления в ВУЗ;

- $\quad$ совершенствование психолого-педагогического уровня преподавателей и командиров подразделений;

- дидактическое проектирование, конструирование и применение профессионально-ориентированной технологии обучения, реализованной на основе моделирования профессиональной деятельности военного специалиста;

- $\quad$ использование своевременной и качественной диагностики и мониторинга сложившегося уровня профессиональной компетентности у слушателей.

Особенность военно-профессиональной компетентности заключается в том, что она реализуется в настоящем, но ориентирована на будущее. Накапливая результаты подготовки военного специалиста (10-15 лет), 
анализируя процесс формирования и развития военно-профессиональной компетенции, первые годы службы офицера в войсках, выявляя его тенденции, закономерности - необходимо выйти на механизм прогнозирования процесса подготовки будущего офицера, без чего невозможно эффективно планировать подготовку военных специалистов. На наш взгляд этому во многом может благоприятствовать внедрение системы анализа отзывов на выпускников через 1, 3, 5, 10 лет после выпуска.

Следовательно, управление образовательным процессом как динамической системой, в основе которой находится компетентностный подход, требует прогнозной информации о перспективах еe развития в интересах повышения эффективности подготовки квалифицированных специалистов.

Таким образом, компетентностный подход является одним из основных условий успешной подготовки военных специалистов и должен опираться на «прогнозно-выделенную» модель, которая, в свою очередь, должна реализовываться с использованием математического аппарата. В противном случае приходится больше полагаться на случайность нежели на четко просчитанный результат. 


\section{Литература}

1. Стратегия модернизации содержания общего образования: Материалы для разработки документов по обновлению общего образования. - М.: 2001

2. Новиков А.М. Методология образования. Издание второе. М.: Эгвес, 2006.

3. Педагогика профессионального образования: Учеб. пособие для студ. высш. пед. учеб. заведений / А.Г. Пашков, Е.П. Белозерцев, А.Д. Гонеев, и др.; Под ред. В.А. Сластенина. М.: Издательский центр «Академия», 2004..

4. Маркова А.К. Психология профессионализма. - М.: Знание, 1996.

5. Талызина Н.Ф., Печенюк Н.Г., Хохловский Л.Б. Пути разработки профиля специалиста. Саратов, 1987.

6. Зимняя И.А. Педагогическая психология. Учебник для вузов. 2-е издание /И.А. Зимняя. - М.: Логос, 2007.

7. Сартан Г. Развитие компетенций: этапы внутрикорпоративного обучения /Г. Сартан//Персонал-Микс. - 2005. -№2. -С.63-66.

8. ФГОС высшего профессионального образования. http://mon.gov.ru/pro/fgos

9. Военная педагогика/ под ред. О.Ю. Ефремова / учебник для вузов. - СПб.: Питер, 2008. - 640 c.

10. Лямзин М.А. Прикладные аспекты проектирования образовательного процесса в СГА в условиях перехода на Федеральные государственные образовательные стандарты. 2010

11. Кравцов Е.В., Нагалин А.В., Сенюков Г.А. «Концептуальная модель оптимизации временных затрат на формирование компетенций на примере подготовки специалистов технической защиты информации». Вестник воронежского института МВД России, выпуск №3/2014. 